\title{
FLUORIDE CONTENT OF SEVERAL BREAKFAST CEREALS AND SNACKS FOUND IN BRAZIL
}

\section{CONTEÚDO DE FLÚOR EM DIVERSOS CEREAIS MATINAIS E SALGADINHOS ENCONTRADOS NO BRASIL}

\author{
Vanessa Eid da Silva CARDOSO, DDS \\ Post-graduation student at the Department of Biochemistry, State University of Campinas, Brazil. \\ Kelly Polido Kaneshiro OLYMPIO, DDS \\ Post-graduation student at the Department of Community Health, Bauru Dental School, University of São Paulo, Brazil. \\ José Mauro GRANJEIRO, DDS, Ms, PhD \\ Marília Afonso Rabelo BUZALAF, DDS, Ms, PhD \\ Associate Professors, at the Department of Biological Sciences, Bauru Dental School, University of São Paulo, Brazil.
}

\begin{abstract}
$B$ reakfast cereals and snacks are foodstuffs highly appreciated by children, and the possibility that they contain substantial amounts of fluoride, associated with their widespread consume, may make them important contributors to the total daily fluoride intake. The aim of this study was to analyze the fluoride content on several breakfast cereals (A) and snacks (B) purchased in Brazil. The analysis were made after HMDS-facilitated diffusion (Taves) using the ion-specific electrode (9609). Mean fluoride concentrations $\pm \mathrm{SD}$ (range, unit $\mu \mathrm{g} \mathrm{F/g}$ ) were: $\mathrm{A}=0.76 \pm$ $0.60(0.08-1.86, \mathrm{n}=15)$ and $\mathrm{B}=0.32 \pm 0.09(0.22-0.55, \mathrm{n}=18)$. Our results suggest that the total amount of fluoride available in some products may contribute to the total daily fluoride intake. The product labels should provide information on their fluoride content to prevent fluorosis at the age of risk.
\end{abstract}

UNITERMS: Fluoride; Cereals; Food analysis; Dental fluorosis.

\section{INTRODUCTION}

It has been demonstrated that the incidence and, to a lesser extent, severity of dental fluorosis has increased in the last decade in both optimally fluoridated and nonfluoridated areas in many countries, as well as in Brazil $^{7,12,18,23}$. Thus, the study of the sources of fluoride intake deserves special attention. Among the main sources of fluoride intake are fluoridated water, powdered milk reconstituted with fluoridated water, inadvertent ingestion of fluoridated toothpaste, inappropriate use of dietary supplements, as well as foods and beverages processed with fluoridated water ${ }^{4,20}$.

The dietary habits during infancy have changed substantially in the last decades and a large increase in the consumption of manufactured products has been observed ${ }^{12}$. Monitoring of the fluoride intake requires knowledge on the fluoride content of the foodstuffs commonly consumed by children at the age of risk for dental fluorosis. Since the manufacturers are not required to have the fluoride content of their products displayed on the labels, it is possible to estimate the fluoride intake only through fluoride assay.

Several previous studies have determined the fluoride content of baby foods, such as milk ${ }^{1,3,14,28}$, dinners and desserts $^{8,13,21,22,25,29}$ and beverages ${ }^{1,5,15}$. However, these studies have been limited mainly to products manufactured in North America.

Little information is available on products from Brazil $^{5,10,24}$. Those available were limited to a very small number of infant foods. Considering that breakfast cereals and snacks are foodstuffs highly appreciated by children, the possibility of containing fluoride among their components may make them important contributors to the total daily fluoride intake. Thus, the aim of the present study was to analyze the total fluoride content of foodstuffs usually consumed by Brazilian children.

\section{MATERIALS AND METHODS}

Nine product samples of breakfast cereals and nine of snacks were purchased in Bauru-SP (Table 1). Brand name, 
food type, flavor, container size, lot number, and manufacturer's name, address, and phone number were recorded for each food and beverage studied.

\section{Preparation and total fluoride analysis}

The products' packages were opened on the day of the analysis. The amount analyzed was $0.20 \mathrm{~g}$. The breakfast cereals and snacks were ground and mixed in $3 \mathrm{~mL}$ of deionized water prior to fluoride analysis. Knowing the exact amount of breakfast cereals and snacks and deionized water used, the fluoride content of the original dry product could be calculated. For the snacks and some breakfast cereals, products manufactured in two different dates (different batches) were analyzed.

Fluoride determinations were carried out after overnight HMDS(hexamethyldisilazane) yl-facilitated diffusion (Taves ${ }^{26}$,1968) using the ion-specific electrode (Orion Research, Cambridge, MA, USA, model 9609). A set of standards (ranging between $0.100-0.800 \mathrm{ppm} F$ ) was prepared, using serial dilution from a $100 \mathrm{ppm} \mathrm{NaF}$ stock solution (Orion\#940907) and diffused in triplicate. The millivoltage potentials were converted to $\mathrm{mg} \mathrm{F}$ using a standard curve with a coefficient correlation of $\mathrm{r}^{3} \mathrm{r}=0.99$. All samples were analyzed in duplicate. The mean repeatability of the readings, based on the duplicate samples, was 90.5 percent.

\section{RESULTS}

Table 1 shows all products analyzed, as well as the manufacturer and production site. Table 2 shows the fluoride concentration $(\mu \mathrm{g} / \mathrm{g})$ determined for all products purchased on two different dates of manufacturing. The mean \pm SD (range, $\mathrm{n}$ ) fluoride concentrations found were $0.76 \pm 0.60$ $(0.08-1.86, \mathrm{n}=15)$ and $0.32 \pm 0.09(0.22-0.55, \mathrm{n}=18)$ for breakfast cereals and snacks, respectively. Most of the products had low fluoride concentrations, except four breakfast cereals (Leite Moça, Nescau, Snow Flakes and Snow Flakes Chocolate) that had mean fluoride concentrations of $1.53 \mu \mathrm{g} / \mathrm{g}(1.26-1.86, \mathrm{n}=5)$. There were small differences in the fluoride concentrations determined for each product on the two different dates of manufacturing (Table 2). However, these differences are not important in terms of fluoride intake.

\section{DISCUSSION}

Many studies have demonstrated that knowledge of the fluoridated water sites is not enough to estimate the total fluoride intake by children, and the fluoride concentration of infant foods and beverages must be known ${ }^{13,17}$. Although it is difficult to precisely determine the total fluoride intake from diet, it is clear that there are substantial variations in

TABLE 1- Breakfast cereals and snacks analyzed

\begin{tabular}{|c|c|c|c|}
\hline Product type & Manufacturer & Production site & Product name \\
\hline \multirow[t]{9}{*}{ Breakfast cereals } & Kellogg's & Santo Amaro-SP & Chocos \\
\hline & & & Froot Loops! \\
\hline & & & Sucrilhos Original \\
\hline & & & Sucrilhos Original Banana \\
\hline & & & Sucrilhos Original Chocolate \\
\hline & Nestlé & Caçapava-SP & Leite Moça \\
\hline & & & Nescau \\
\hline & & & Snow Flakes Original \\
\hline & & & Snow Flakes Chocolate \\
\hline \multirow[t]{9}{*}{ Snacks } & Elma Chips & Itu-SP/Curitiba-PR/Sete & Cheetos Queijo Temperado \\
\hline & & Lagoas-MG & Cheetos Requeijão \\
\hline & & & Fandangos Queijo \\
\hline & & & Fandangos Pizza \\
\hline & & & Fandangos Presunto \\
\hline & Fritex & São Roque-SP & Sítio* Batata \\
\hline & & & Sítio*Cebola \\
\hline & & & Sítio* Pizza \\
\hline & & & Sítio* Requeijão \\
\hline
\end{tabular}


the intake of different foods and beverages and in the fluoride content of these products. Since products are not required to have their fluoride content displayed, the dietary fluoride intake may only be determined through fluoride assay.

The optimal range of fluoride intake is considered to be of $0.05-0.07 \mathrm{mg} \mathrm{F} / \mathrm{kg}$ body weight/day ${ }^{2,12}$. Most products analyzed in this study had low fluoride concentration (mean fluoride concentration was 0.76 and $0.32 \mu \mathrm{g} / \mathrm{g}$ for breakfast cereals and snacks, respectively). The fluoride concentrations found in breakfast cereals (Table 2 ) are within the same range as those reported in infant cereals by Vlachou, et al. ${ }^{29}$, Wiatrowski, et al ${ }^{30}$. (0.63 to $1.17 \mu \mathrm{g} \mathrm{F} / \mathrm{g}$ ), Dabeka, et al. ${ }^{8}$ (1.24 to $4.89 \mu \mathrm{g} \mathrm{F/g}$ ), Buzalaf, et al. ${ }^{3}$ (0.43 to $6.64 \mu \mathrm{g}$ $\mathrm{F} / \mathrm{g}$ ) and Buzalaf, et al. ${ }^{5}$ (0.20 to $7.84 \mu \mathrm{g} \mathrm{F} / \mathrm{g}$ ); there was a consistency of values obtained from the same product manufactured on different dates. The amount of fluoride in most of these products suggests that they may not significantly contribute to the daily fluoride intake.

However, four products analyzed (Leite Moça, Nescau, Snow Flakes and Snowm Flakes Chocolate) had considerable fluoride concentrations (mean fluoride concentration of $1.54 \mu \mathrm{g} / \mathrm{g}$ ) and may be considered additional risk factors for dental fluorosis, especially when associated to other fluoride sources (Table 2). The breakfast cereals that had the highest fluoride concentration were calcium- rich products (12\% calcium), as displayed on their labels. The high fluoride concentrations found in these products may be due to the calcium source added during manufacturing. Since the presence of calcium may diminish the fluoride absorption by the gastro-intestinal $\operatorname{tract}^{27}$, it is possible that these calcium-rich cereals contribute little to dietary fluoride bioavailability.

One important factor to be considered is that breakfast cereals are usually mixed with milk. When $30 \mathrm{~g}$ (one package) of Leite Moça, Nescau, Snow Flakes and Snow Flakes Chocolate are consumed just once a day, it means approximately $0.05 \mathrm{mg} \mathrm{F}$, which may provide $5-7 \%$ of the maximum total desirable fluoride intake per day $(0.07 \mathrm{mg}$ $\mathrm{F} / \mathrm{kg}$ body weight /day) for a 2 -year-old child, weighing around $12 \mathrm{~kg}^{2,12}$. If $30 \mathrm{~g}$ of those products are added to $125 \mathrm{~mL}$ of milk, as recommended on the labels, the fluoride content of the milk or other liquid must be considered. Cow's milk is known to have a low fluoride content ${ }^{16}$, yet powdered or liquid concentrated infant formulas may also be used. Therefore, the fluoride present in the water used to reconstitute these formulas must be considered. Furthermore, some children mix these breakfast cereals with ready-todrink chocolate milks and some of them have been shown to have a high fluoride content ${ }^{5}$. In addition, another liquid that may also be mixed to the breakfast cereals is soy milk,

TABLE 2- Fluoride content (mean unit $\mu \mathrm{g} / \mathrm{g}$ ) of breakfast cereals and snacks in two different dates of manufacturing (different batches)

\section{Product type}

Breakfast cereals

Snacks

\section{Product name}

Chocos

Froot Loops!

Sucrilhos Original

Sucrilhos Original Banana

Sucrilhos Original Chocolate

Leite Moça

Nescau

Snow Flakes Original

Snow Flakes Chocolate

Cheetos Queijo Temperado

Cheetos Requeijão

Fandangos Queijo

Fandangos Pizza

Fandangos Presunto

Sítio** Batata

Sítio**Cebola

Sítio** Pizza

Sítio** Requeijão

\section{Fluoride concentration}

Batch 1

Batch 2*
$0.29 \quad 0.46$

$0.08 \quad 0.13$

$0.55 \quad 0.44$

$0.62 \quad 0.36$

0.29

0.48

1.69

1.26

1.40

1.44

1.86

0.22

0.25

0.38

0.27

0.22

0.32

0.24

0.24

0.28

0.26

0.34

0.26

0.35

0.29

0.35

0.55

0.40

0.50

\footnotetext{
*Only one batch was analyzed for some products

**Sítio do picapau amarelo
} 
which contains higher fluoride contents than cow's milk ${ }^{3,27}$, and this has been attributed to higher endogenous levels of fluoride in the soy extract.

The high fluoride content for those four breakfast cereals may be explained by their manufacturing process. During manufacturing, infant dry cereals are processed in a slurry and placed in a revolving drying drum. The water from the slurry evaporates, and the fluoride from the water remains in the cereal. Thus, the fluoride concentration of the water used during processing can substantially affect the final fluoride concentration. Fomon and Ekstrand reported that fluoride concentrations in dry cereals produced with nonfluoridated or fluoridated water ranged from 0.09 to 0.20 and from 4 to $6 \mu \mathrm{g} \mathrm{F} / \mathrm{g}$, respectively ${ }^{11}$.

Another factor that must be taken into account is the use of non-fluorine or fluorine-containing fertilizers in the grain grow plots. A study was made of the fluorine-ion content in the vegetables and grain grown on experimental plots of land fertilized for 4-6 years with fluorine-containing fertilizers, and the fluorine-ion content in individual samples of the vegetables and grain was found to increase 2-32-fold as compared to the control ${ }^{19}$.

Our results showed that there was no significant variation in the fluoride concentration between the products analyzed in two different dates of manufacturing. This was also observed for Brazilian manufactured foods ${ }^{5}$. We tested this variable because the fluoride concentrations for the majority of the products vary primarily as a function of the different fluoride concentrations in the water used to process them ${ }^{15}$ and fluctuations in water fluoride concentrations are very common ${ }^{6}$. While this indicates that there may be no significant variation in the fluoride content of the water source at those specific locations, this assumption may not be extrapolated to other products manufactured at other sites.

Another crucial factor when the association between fluorosis and infant foods is considered is the critical period of fluoride exposure for fluorosis development. Evans, Darvell $^{9}$ (1995) showed that the maxillary central incisor appears most at risk to fluorosis from dietary fluoride between fifteen and twenty-four months of age for males and twenty-one and thirty months of age for females. This way, the critical period for the anterior permanent teeth would be after the first twelve months of life. At this time, there is an increase in fluoride intake from manufactured products.

This work showed that some breakfast cereals analyzed should be important contributors to total daily fluoride intake when associated with other fluoride-containing product. The product labels should provide information on their fluoride content.

\section{RESUMO}

Cereais matinais e salgadinhos são guloseimas altamente apreciadas pelas crianças, e a possibilidade de conterem quantidades substanciais de flúor, associada ao seu indiscriminado consumo, pode torná-los importantes contribuintes para a ingestão diária total de flúor. O objetivo deste estudo foi analisar o conteúdo de flúor em diversos cereais matinais (A) e salgadinhos (B) adquiridos no Brasil. As análises foram feitas após difusão facilitada por HMDS (Taves), usando o eletrodo íon específico (9609). As concentrações médias de flúor \pm SD (amplitude, unidade $\mu \mathrm{g} \mathrm{F} / \mathrm{g})$ foram: $\mathrm{A}=0,76 \pm 0,60(0,08-1,86, \mathrm{n}=15)$ e $\mathrm{B}=0,32$ $\pm 0,09(0,22-0,55, \mathrm{n}=18)$. Nossos resultados sugerem que a quantidade de flúor presente em alguns produtos pode contribuir com a ingestão diária total de flúor. Os rótulos dos produtos deveriam informar seu conteúdo de flúor para prevenir fluorose no período de risco.

UNITERMOS: Flúor; Cereais; Análise de alimentos; Fluorose dental.

\section{REFERENCES}

1- Adair SM, Wei HY. Supplemental fluoride recommendations for infants based on dietary fluoride intake. Caries Res, 1978: 12 (2): 76-82.

2- Burt BA. The changing patterns of systemic fluoride intake. J Dent Res 1992; 71: 1228-37.

3- BUZALAF MAR, Granjeiro JM, Damante CA, Ornelas F. Fluoride content of infant formulas prepared with deionized, bottled mineral and fluoridated drink water. J Dent Child 2001; 68(1):37-41.

4- Buzalaf MAR, Whitford GM, Cury JA. Fluoride exposures and dental fluorosis: a literature review. Rev Fac Odontol Bauru 2001; 9(1):1-10.

5- Buzalaf MAR, Granjeiro JM, Duarte JL, Taga ML. Fluoride content of infant foods in Brazil and risk of dental fluorosis. ASDC J Dent Child 2002; 69(2):196-200.

6- Buzalaf MAR, Granjeiro JM, Damante CA, Ornelas F. Fluctuations in public water fluoride level en Bauru, Brazil. J Public Health Dent 2002; 62:173-6.

7- Correia Sampaio F, Ramm von der Fehr F, Arnberg P, Petrucci Gigante D, Hatloy A. Dental fluorosis and nutritional status of 6to 11-year-old children living in rural areas of Paraiba, Brazil. Caries Res 1999; 33 (1): 66-71.

8- Dabeka RW, McKenzie AD, Conacher HBS, Kirkpatrick DC Determination of fluoride intakes by infants. Can J Public Health, 1982; 73: 188-91.

9- Evans WR, DarvelL BW. Refining the estimate of the critical period for susceptibility to enamel fluorosis in human maxillary central incisors. J Publ Health Dent 1995; 55 (4): 238-49.

10- Fernandes DRM, Tabchoury CM, Cury JA. Concentração de flúor em alimentos infantis e risco de fluorose dental. Pesq Odont Bras 2000; 14(supp): 47 (Abs I289).

11- Fomon SJ, Ekstrand J. Fluoride intake by infants. J Public Health Dent 1999; 59 (4): 229-34. 
12- Fomon SJ, Ekstrand J, Ziegler EE. Fluoride intake and prevalence of dental fluorosis: trends in fluoride intake with special attention to infants. J Public Health Dent 2000 60(3):131-9.

13- Heilman JR, Kiritsy MC, Levy SM, Wefel JS. Fluoride concentrations of infant foods. J Am Dent Ass 1997; 128: 85763.

14- Howat AP, Nunn JN. Fluoride levels in milk formulations. Brit Dent J, 1981; 150: 276-8.

15- Kiritsy MC, Levy SM, Warren JJ, Guha-Chowdhury N, Heilman JR, Marshall T. Assessing fluoride concentrations of juices and juice-flavored drinks. J Am Dent Ass 1996; 127:895902.

16- Larsen MJ, Senderovitz F, Kirkegaard E, Poulsen S, Fejerskov $\mathrm{O}$. Dental fluorosis in the primary and permanent dentition in fluoridated areas with consumption of either powdered milk or natural cow's milk. J Dent Res 1988; 67: 822-5.

17- Levy SM, Kiritsy MC, Warren JJ. Sources of fluoride intake in children. J Publ Health Dent 1995; 55: 39-52.

18- Levy SM, Warren JJ, Davis CS, Kirchner HL, Kanellis MJ, Wefel JS. Patterns of fluoride intake from birth to 36 months. J Public Health Dent 2001; 61: 70-7.

19- Lykova AS, Mitrofanova AI, Skachkov MA. Effect of rations containing fluorine ion on biochemical and hematological indices of body status Vopr Pitan 1981; 6: 46-7.

20- Mascarenhas A K. Risk factors for dental fluorosis: a review of the recent literature. Pediatr Dent 2000; 22: 269-77.

21- Ophaug RH, Singer L Harland BF. Estimated fluoride intake for 6-month-old infants in four dietary regions of the United States. Am J Clin Nutr, 1980; 33: 324-7.

22- Ophaug RH, Singer L, Harland BF. Dietary fluoride intake of 6-month and 2-year-old children in four dietary regions of the United States. Am J Clin Nutr 1985; 42: 701-7.

23- Pereira AC, Da Cunha FL, Meneghim MD, Werner CW. Dental caries and dental fluorosis prevalence study in a nonfluoridated Brazilian community: trend analysis and toothpaste association. ASDC J Dent Child 2000; 67: 132-5.

24- PIN MLG, Oliveira FS, Silva MSB, Buzalaf MAR, Machado MAM, Granjeiro JM. Concentração de flúor no leite, sucos, refrigerantes e alimentos infantis. Pesq Odont Bras 2000; 14(supp): 136, (Abs B231).

25- Rojas-Sanches F, Kelly SA, Drake KM, Eckert GJ, Stookey GK, Dunipace AJ. Fluoride intake from foods, beverages and dentifrice by young children in communities with negligibly and optimally fluoridated water: a pilot study. Comm Dent Oral Epidemiol 1999; 27:288-97.

26- Taves DR. Separation of fluoride by rapid diffusion using hexamethyldisiloxane. Talanta, 1968; 15: 969-74.
27- Trautner K, Siebert G. An experimental study of bioavailability of fluoride from dietary sources in man. Arch Oral Biol 1986; 31: 223-8.

28- Van Winkle S, Levy SM, Kiritsy MC. Water and formula fluoride concentrations: significance for infants fed formula. Pediatr Dent 1995; 17: 305-10.

29- Vlachou A, Drummond BK, Curzon MEJ. Fluoride concentrations of infant foods and drinks in the United Kingdom. Caries Res 1992; 26: 29-32.

30- Wiatrowski E, Kramer L, Osis D, Spencer H. Dietary fluoride intake of infants. Pediatrics 1975; 55: 517-22.

Recebido para publicação em: 07/02/2003

Enviado para reformulações em: 26/05/2003

Pronto para publicação em: 11/06/2003

Corresponding address:

Department of Biological Sciences, Bauru Dental School, University of São Paulo, Brazil.

Dr. Marília Afonso Rabelo Buzalaf

Al. Octávio Pinheiro Brisolla, 9-75

Bauru-SP

Brazil

17012-901 